\title{
Measuring the Effectiveness of e-learning in Public Sector
}

\author{
Herina Nurhayati ${ }^{1, *} \&$ R. Rachmawati ${ }^{2}$ \\ ${ }^{1}$ University of Indonesia, Jakarta, Indonesia \\ ${ }^{2}$ University of Indonesia, Jakarta, Indonesia \\ "Corresponding author. Email: herina.lifelight@gmail.com
}

\begin{abstract}
Electronic learning (e-learning) has been widely adopted by many companies as a strategic tool for the learning and development of their employees, mainly for time and cost-saving. This study aims to assess the effectiveness of e-learning using six constructs of the updated DeLone and McLean information system success model (DMISM) with the extending role of employees' learning motivation. While IS success models have received much attention among researchers, little research has been conducted to assess the success and effectiveness of e-learning systems in the organizational context, especially in the public sectors. Data gathered from 962 employees in Indonesia's public sector was tested using structural equation modeling (SEM). The research model was able to explain $66 \%$ variance of system use, $88 \%$ variance of user satisfaction, and $73 \%$ variance of net impact. Learning motivation as an expanded variable was proven successful as a predictor for system use and user satisfaction.
\end{abstract}

Keywords: e-learning effectiveness, learning motivation, IS Success Model, public sector.

\section{INTRODUCTION}

In the skill-based economy era, knowledge is an essential resource for organizations that could form the basis of competitive advantage (Kapo et al. 2020, Li \& Tsai 2020). Therefore, modern organizations are facing the biggest challenge of knowledge competition. As the most valuable asset for organizations, employees need to be developed continuously to make knowledge acquisition in companies faster than the rapid flow of information itself (Lalic et al. 2017). In this sense, both public and private companies are required to make an effort aimed at increasing employees' performances and implement organizational learning and knowledge management practices (Stoffregen et al. 2015).

The growth of Society 5.0 that built upon Industry 4.0 also plays a vital role. Society 5.0 focuses on humanism by prioritizing scientific and technological innovation with the primary development purpose in the economic sector (Fukuyama 2018, Sudibjo et al.
2019). Learners in the era of Industry 4.0 and Society 5.0, who are technology-savvy, can obtain information anywhere and anytime quickly. Almost all of them have access to technology (Sudibjo et al. 2019). In the technology era, knowledge emphasizes access to allow people to pursue their passion and goal and provide people a rich social learning space to learn what they choose (Collins \& Halverson 2018, Sudibjo et al. 2019). Organizations may play an active role by balancing technology integration and investment in human resource development as a critical point in increasing employee productivity (Schwab 2019).

This phenomenon makes learning that utilizes technology and information or elearning gain popularity nowadays ( $\mathrm{Li} \&$ Tsai 2020, Serrat 2017). E-learning refers to using computer network technology, either via the internet or intranet, to convey information and instructions to employees ( $\mathrm{Za}$ reie \& Navimipour 2016). E-learning can be defined as web-based learning that utilizes 
web-based communication, collaboration, multimedia, knowledge transfer, and training to support participants to engage in active learning without space and time constraints (Lee et al. 2009). According to Alshaher (2013), e-learning is learning with electronic means and adding knowledge and skills using electronic technology such as computers, web-based training programs, intranet, and internet networks.

E-learning enables the simultaneous spread of knowledge transfer that can be accessed by a wide variety of people (Hussein 2018, Martins et al. 2019, Zareie \& Navimipour 2016). It allows the transfer to occur more quickly to update the employees' skills and knowledge rapidly. The proliferation of e-learning as a learning tool is due to the benefits of e-learning, such as flexibility (Alshaher 2013, Chen 2014, Hussein 2018, Martins et al. 2019, Sawang et al. 2013, Tanduklangi 2017), cost efficiency (Hussein 2018), and delivery efficiency (Alshaher 2013, Chen 2014, Hussein 2018, Sawang et al. 2013).

To fully grasp the benefit of e-learning as a strategic tool for learning in organizations, it is crucial to assess the effectiveness of elearning. As e-learning is a type of information system (IS) and its success is a complex concept, it must be assessed with multidimensional factors. Organizations who invest in an IS expecting it to answer business challenges and opportunities. Therefore, assessing the success of an IS in helping the organization achieves its goals is an important thing (DeLone \& McLean 2016). To predict and explain user behavior with technology, many theories and models have been developed, such as DeLone and McLean Model of Information System Success (DMISM) (DeLone \& McLean 1992, 2003, 2016); technology acceptance model (Davis 1989), diffusion of innovation theory (Rogers 1995); and unified theory of acceptance and use of technology (Venkatesh et al. 2003). However, only DMISM evaluates the effectiveness of information systems by examining the effect of system quality, information quality, and service quality on user satisfaction and system use, both of which influence the net impact on using the system (In this context is e-learning).

DMISM provides a theoretical basis for linking human systems to the beneficial consequences of using an information system (DeLone \& McLean 1992, 2003, 2016, Seddon 1997).

The first version of DMISM has six main dimensions: System Quality, Information Quality, System Use, User Satisfaction, Individual Impact, and Organization Impact. This model confirms that the IS characteristics influence the system use and user satisfaction with the system. There is a causal relationship between the two, and both influence the individual, which will ultimately impact the organization (DeLone \& McLean 1992). Furthermore, the development of this model is carried out against the background of various criticisms and challenges and to accommodate the growing e-commerce phenomenon. Thus, in 2003, DeLone and McLean developed the model by adding the Service Quality variable, a critical element in the e-commerce environment.

Besides, there are additions to Intention to Use to measure users' attitudes. This is because in some cases, such as in mandatory use of IS, the benefit is considered not sufficiently valid. Based on the various outcomes that may occur from using an IS, DeLone and McLean do not explicitly state outcomes in this respecification model but are merged into one, which is called net benefits. The benefits of using IS will bring satisfaction and encouragement to reuse it.

Consequently, in this respecification model, DeLone and McLean add a mutually influencing relationship between the impact of IS use and intention to use with user satisfaction (DeLone \& McLean 2013). More than a decade later, in 2016, DeLone and McLean again refined the IS Success Model by changing the net benefits variable to net impacts. According to them, net benefits tend to lead only to positive benefits from using an information system.

In contrast, the impacts of using IS are extensive and may bring positive and negative 
effects. These perceived impacts will ultimately affect the subsequent use of an IS as well as user perceived satisfaction. In addition, from a literature study conducted on one of the studies using their model, DeLone and McLean reveal that other factors can affect the variables of system quality, information quality, and service quality in their model (DeLone \& McLean 2016). DMISM has been widely adopted in research that aimed to assess the effectiveness of an IS, including the effectiveness of e-learning (Aldholay et al. 2020, Aldholay et al. 2018, Al-Fraihat et al. 2020, Aparicio et al. 2019, Chen \& Kao 2012, Mohammadi 2015).

As an andragogical learning, learning in a workplace emphasizes employee's high motivation to learn and be actively involved in the process. Flexibility in e-learning requires employees to control the time, space, and rhythm of learning by themselves. Greater motivation from employees is required to persist and engage in e-learning, more than what is needed in face-to-face training (Martins et al., 2019). Therefore, the role of learning motivation as an indicator of the stimulation of human needs as a driver for one's actions to meet learning needs is significant (Chen \& Kao 2012). Learning motivation reflects a person's attachment and contribution to the learning environment. Attachment from learning may come from the employee's need for professional advancement, the desire for learning achievement, and the influence from others (Chen \& Kao 2012).

It is worth noting that the majority of studies utilizing the DMISM were found in western countries and the education sector (Al-Fraihat et al. 2020, Aparicio et al. 2019, Cidral et al. 2020, Cidral et al. 2018, Martins et al. 2019). However, this study aims to utilize the DMISM theory in Indonesia's public sectors, in which the culture and context are vastly different. It also extends the role of DMISM with employee's learning motivation to clarify the importance of learning motivation in employees' self-directed, autonomous e-learning for productivity. The findings may provide essential insights for organizations, especially in public sectors, to increase the effectiveness of e-learning.

\section{RESEARCH METHODS}

This study used a quantitative research method. Data were collected through online questionnaires by Google Form. Respondents were employees in public organizations in Indonesia who have completed at least one e-learning course in the past year. Based on the aims, the purposive sampling technique was applied in this study (Sekaran \& Bougie 2013).

Respondents were asked to fill 31-item questions adapted from various studies. This study applied a few best items in the number of questions in each construct since additional redundant items provide less research benefit (Hayduk \& Littvay 2012). System quality and information quality were measured through 3 and 5-item questions adapted from Aldholay et al. (2018). The service quality scale consists of four items (Urbach et al., 2010; Aparicio et al., 2019). Learning motivation measurement was adapted from Chen \& Kao (2012) and had three dimensions with a 3-item question for each dimension. The use of e-learning was measured through a 3-item question adapted from Chen \& Kao (2012). User satisfaction was assesed through a 3-item question adapted from Aldholay et al. (2018). Lastly, the net impact was measured through a 4item question adapted from Urbach et al. (2010) and Aparicio et al. (2019). Due to the possible effect of the environmental intervention and the intangible impact realized from e-learning, net impact in this study was referred to the perceived effects of employees, especially in employee task performance. Task performance is not only sufficient to measure the impact of using elearning by employees, but it also is an expected goal of the organization's efforts to use e-learning (Chen \& Kao 2012).

All questions were using a six-point Likert scale $(1="$ strongly disagree"; $6="$ strongly agree"). The selection of even ranges was 
made to avoid the central-tendency bias since Asians tend to choose the middle point on the answer scale compared to Americans (Lee et al. 2002). Hence, while the research uses multiple-rating instruments, the use of an even scale will be more effective in measuring and expressing the valid opinion of the population in Asian countries. It will increase the variance and avoid weakening the relationship strength of a variable ( $\mathrm{Si} \&$ Cullen 1998).

This is a cross-sectional study with monthly data collection (March 2021). 962 responses were collected. The data were analyzed using structural equation modeling using the LISREL software.

\section{RESULTS AND DISCUSSION}

The measurement model in this research is developed based on literature reviews and models from related previous studies. Drawing from DMISM (DeLone \& McLean 1992, 2003, 2016) and the learning motivation model (Chen \& Kao 2012), the model of this research is shown in Figure 1.

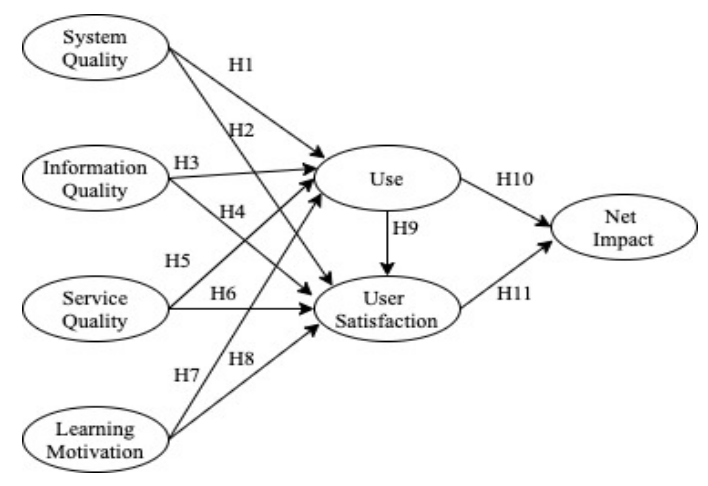

Figure 1. Research Model

Assessment of measurement model validity through Confirmatory Factor Analysis (CFA) is carried out to assess how well the construct components represent the measurement model, before being analyzed further. From the CFA results, the validity and reliability of each indicator are obtained as well as the dimensions that make up the con- struct. A construct is declared valid if it meets the convergent validity criteria, which can be measured in several ways, including standardized factor loading (SFL) and average variance extracted (AVE) that must be greater than 0.5 and construct reliability (CR) that must be greater than 0.7 (Hair et al. 2014).

The indicators used in this study were 31 items. CFA results show that all indicators have exceeded the minimum value required to be declared valid and reliable. Therefore, they could proceed to further analysis.

The next step is to conduct a structural model analysis to assess the suitability of the model built as a whole with the tested sample. The structural model analysis is done by comparing the criteria for the Goodness-ofFit (GOF) measure with the GOF size in the study. The research model of this study passes the GOF criteria with the GFI Index score of 0.91; Root Mean Square Error of Approximation (RMSEA) is 0.061; and the scores on incremental fit indices criteria (Normed Fit Index, Non-normed Fit Index, Comparative Fit Index, Relative Fit Index, and Incremental Fit Index) all shown the score of 0.99 , which means the model is a good fit (Hair et al. 2014). Details of the GOF result are shown in Table 1.

Table 1. Values of Goodness of Fit and Structural Model

\begin{tabular}{|c|c|c|c|c|}
\hline$G O F$ & Criteria & $\begin{array}{c}\text { Cut-off } \\
\text { Value }\end{array}$ & $\begin{array}{l}\text { Model } \\
\text { Test } \\
\text { Value }\end{array}$ & Result \\
\hline \multirow{3}{*}{$\begin{array}{l}\text { Absolute } \\
\text { Fit Indices }\end{array}$} & GFI & $\geq 0.90$ & 0.91 & Good \\
\hline & RMSEA & $\begin{array}{l}0.05 \quad \geq \\
\text { RMSEA } \\
\leq 0.08\end{array}$ & 0.061 & $\begin{array}{l}\text { Good } \\
\text { Fit }\end{array}$ \\
\hline & SRMR & $\leq 0.05$ & 0.039 & $\begin{array}{l}\text { Good } \\
\text { Fit }\end{array}$ \\
\hline \multirow[t]{5}{*}{$\begin{array}{l}\text { Incremental } \\
\text { Fit Indices }\end{array}$} & NFI & $>0.9$ & 0.99 & Good \\
\hline & NNFI & $>0.9$ & 0.99 & Good \\
\hline & CFI & $>0.9$ & 0.99 & $\begin{array}{l}\text { Good } \\
\text { Fit }\end{array}$ \\
\hline & RFI & $>0.9$ & 0.99 & $\begin{array}{l}\text { Good } \\
\text { Fit }\end{array}$ \\
\hline & IFI & $>0.9$ & 0.99 & $\begin{array}{l}\text { Good } \\
\text { Fit }\end{array}$ \\
\hline
\end{tabular}


Hypothesis testing is done by comparing the t-values obtained from the output path diagram with the specified t-table values. In this study, a 95\% confidence level was determined. Judging from the research hypothesis that tests the positive relationship between variables, the hypothesis uses a onetailed test approach. Therefore, the t-table value used in this study is 1.645 . It means that the relationship between variables is significant (the hypothesis is accepted) if it has a t-value of more than 1.645. The path coefficients, the t-Values for each path, and the significance of the hypothesis are shown in Table 2. From eleven (11) hypotheses proposed, ten (10) associations are verified and significant. However, one hypothesis that predicted a positive and significant effect between information quality and use is insignificant.

Table 2. Hypothesis Testing Results

\begin{tabular}{l|cccc}
\hline Hypothesis & $\begin{array}{c}\text { Path- } \\
\text { coefficient }\end{array}$ & $\begin{array}{c}\text { S.E. } \\
\text { Standard } \\
\text { Errors }\end{array}$ & $\begin{array}{c}t \text { - } \\
\text { Value }\end{array}$ & Sig \\
\hline H1 SyQ $\rightarrow$ & 0.19 & 0.06 & 3.35 & $\mathrm{~S}$ \\
$\mathrm{U}$ & 0.11 & 0.04 & 2.63 & $\mathrm{~S}$ \\
$\mathrm{H} 2 \mathrm{SyQ} \rightarrow$ & & & & \\
$\mathrm{US}$ & & 0.06 & 1.15 & $\mathrm{NS}$ \\
$\mathrm{H} 3 \mathrm{IQ} \rightarrow \mathrm{U}$ & 0.06 & 0.04 & 6.44 & $\mathrm{~S}$ \\
$\mathrm{H} 4 \mathrm{IQ} \rightarrow \mathrm{US}$ & 0.27 & 0.04 & 3.93 & $\mathrm{~S}$ \\
$\mathrm{H} 5 \mathrm{SeQ} \rightarrow$ & 0.16 & & & \\
$\mathrm{U}$ & & 0.03 & 3.34 & $\mathrm{~S}$ \\
$\mathrm{H} 6 \mathrm{SeQ} \rightarrow$ & 0.10 & & & \\
$\mathrm{US}$ & & 0.04 & 11.45 & $\mathrm{~S}$ \\
$\mathrm{H} 7 \mathrm{LM} \rightarrow \mathrm{U}$ & 0.49 & 0.04 & 6.70 & $\mathrm{~S}$ \\
$\mathrm{H} 8 \mathrm{LM} \rightarrow$ & 0.24 & & & \\
$\mathrm{US}$ & & & & \\
$\mathrm{H} 9 \mathrm{U} \rightarrow \mathrm{US}$ & 0.33 & 0.04 & 9.15 & $\mathrm{~S}$ \\
$\mathrm{H} 10 \mathrm{U} \rightarrow \mathrm{NI}$ & 0.27 & 0.04 & 5.56 & $\mathrm{~S}$ \\
$\mathrm{H} 11 \mathrm{US} \rightarrow$ & 0.61 & 0.05 & 12.33 & $\mathrm{~S}$ \\
$\mathrm{NI}$ & & & & \\
\hline
\end{tabular}

System and service quality proved to be an important predictor of use in this study. These results are in line with the DMISM theory (DeLone \& McLean 1992, 2003, 2016) and the results of previous studies (Aldholay et al. 2020; Al-Fraihat et al. 2020; Marjanovic et al. 2016; Mohammadi 2015). However, information quality does not affect the use of e-learning significantly since the nature of e-learning is partially mandatory. It means that, to some extent, employees are still required to use the e-learning system even though the information provided was general knowledge and not directly relevant to their current job. Previous studies also show that the quality of information does not significantly affect system usage (Al-Fraihat et al., 2020; Aparicio et al., 2019; Chen, 2010)

System quality, information quality, service quality, and system use are significant antecedents of user satisfaction in terms of user satisfaction. These results corresponded to the DMISM theory (DeLone \& McLean $1992,2003,2016)$ and results of the past research (Al-Fraihat et al. 2020, Aldholay et al. 2020, Aldholay et al. 2018, Tam \& Oliveira 2016).

The expansion of the DMISM model with learning motivation variables is proved successful in this study. Learning motivation is proven to be a significant predictor of both use and user satisfaction. Learning motivation is the factor that most influences the use of e-learning for employees in the public sectors. It is indicated by the path coefficient value of learning motivation to e-learning use which is the highest compared to other factors. These results are in line with the previous related research conducted by Chen \& Kao (2012), Ramayah et al. (2012), Sawang et al. (2013). From the three dimensions of learning motivation, learning achievement is the most significant predictor, followed by professional advancement and influence of others.

As for the net impact, DMISM theory states that it is influenced by system use and user satisfaction. The theory is supported in this research, while both use and user satisfaction are proven as the significant antecedents of net impact. Previous research has also proven this relationship (Aldholay et al. 2020, Aldholay et al. 2018, Al-Fraihat et al. 2020, Aparicio et al. 2019, Cidral et al. 2020). As for the effect size, in this study, user satisfaction is a more dominant predictor compared to system use. User satisfaction could explain $61 \%$ of the net impact, while system use could explain $27 \%$ of the net impact. Altogether, as shown in Table 3, this study's model can explain $66 \%$ variance 
of system use, $88 \%$ variance of user satisfaction, and $73 \%$ variance of net impact.

Table 3. R-Square Results

\begin{tabular}{|c|c|c|}
\hline & $R$-Square & Independent Variables \\
\hline Use & $66 \%$ & $\begin{array}{l}\text { System Quality, Infor- } \\
\text { mation Quality, Service } \\
\text { Quality, Learning Motiva- } \\
\text { tion }\end{array}$ \\
\hline $\begin{array}{l}\text { User Satis- } \\
\text { faction }\end{array}$ & $88 \%$ & $\begin{array}{l}\text { System Use, System Qual- } \\
\text { ity, Information Quality, } \\
\text { Service Quality, Learning } \\
\text { Motivation }\end{array}$ \\
\hline Net I & $73 \%$ & $\begin{array}{l}\text { System Use, User Satis- } \\
\text { faction }\end{array}$ \\
\hline
\end{tabular}

\section{CONCLUSION}

In Society 5.0, technological innovation is implemented in various aspects, including in the employee's learning program. Therefore, e-learning as a part of human resources development programs is adopted by many organizations, including public sectors. Being more than a learning tool, e-learning effectiveness needs to be assessed to justify that organizations' investments in e-learning have fulfilled their purpose.

This study has successfully proven the DMISM theory of e-learning in public organizations. To enrich the understanding, this study also proves the significant role of learning motivation as a factor affecting system use and user satisfaction of e-learning. Hence, the results of this study may be a reference for management to improve the effectiveness of e-learning in organizations in general and public organizations in particular.

From a management perspective, several recommendations can be given based on the results of this study. First, this study offers a model for assessing the effectiveness of elearning in public sectors (use, user satisfaction, and net impact) and which factors may substantially impact such success. Therefore, the organizations aimed to increase the effectiveness of e-learning should pay close attention to these factors, i.e., increasing flexibility of e-learning as one of the value propositions offered. Organizations may try to provide e-learning on various platforms, not just web-based e-learning, but also an integrated learning application that could be easily installed and accessed on the employees' mobile phone. Second, the public sector must create a good learning environment to engage employees in e-learning activities and foster employees' satisfaction with elearning. By doing so, it is expected that the effectiveness of e-learning would increase, as user satisfaction was found to be a significant antecedent of net impact. The employee who feels satisfied with e-learning programs also can share the positive experience with others. This, in turn, will increase other employees' learning motivation, as the influence of others also has a role in determining it. Therefore, maximizing user satisfaction with e-learning will increase e-learning's net impact and create a network effect for escalation of e-learning use. Third, regarding the critical role of learning motivation for elearning effectiveness, organizations have to pay more attention to this part. It can be done through various ways, such as providing badges and enhancing the gamification experience on e-learning to give employees a sense of learning achievement.

Future research is expected to investigate further the role of gamification as a determinant of the effectiveness of e-learning. Gamification has a promising future in $\mathrm{e}$ learning, not only because it can increase employee's learning motivation but also could affect employees' perceived enjoyment of e-learning, which is one of the variables used in the Technology Acceptance Model (TAM) (Davis 1989). Therefore, future research could incorporate DMISM and TAM with the extending role of gamification.

\section{REFERENCES}

Aldholay, A., Abdullah, Z., Isaac, O., \& Mutahar, A.M. 2020. Perspective of Yemeni students on use of online learning. Information Technology \& People 33 (1): 106-128

Aldholay, A.H., Isaac, O., Abdullah, Z., \& Ramayah, T. 2018. The role of transformational leadership as mediating variable in DeLone and McLean Information System Success Model: The context of 
online learning usage in Yemen. Telematics and Informatics 35(5): 1421-1437.

Al-Fraihat, D., Joy, M. Masa'deh, R., \& Sinclair, J. 2020. Evaluating e-learning system success: An empirical study. Computers in Human Behavior 102: 67-86.

Alshaher, A, A. 2013. The McKinsey 7 model framework for e-learning system readiness assessment. International Journal of Advances in Engineering \& Technology 6 (5): 1948-1966.

Aparicio, M., Oliveira, T., Bacao, F. \& Painho, M. 2019. Gamification: A key determinant of massive open online course (MOOC) success. Information \& Management 56: 39-54.

Chen, H. 2010. Linking employees' e-learning system use to their overall job outcomes: An empirical study based on the IS success model. Computers \& Education 55: 1628-1639.

Chen, H. \& Kao, C. 2012. Empirical validation of the importance of employees' learning motivation for workplace e-learning in Taiwanese organizations. Australasian Journal of Educational Technology 28 (4): 580-598.

Chen, T. 2014. Exploring e-learning effectiveness perceptions of local government staff based on diffusion of innovations model. Administration \& Society 46 (4): 450-466.

Cidral, W., Aparicio, M., \& Oliveira, T. 2020. Students' long-term orientation role in e-learning success: A Brazilian study. Heliyon 6: 1-12.

Cidral, W.A., Oliveira, T., Felice, M. D., \& Aparicio, M. 2018. E-learning success determinants: Brazilian empirical study, Computers \& Education 122(July): 273-290.

Collins, A., \& Halverson, R. (2018). Rethinking Education in the Age of Technology. New York: Teachers College Press.

Davis, F. D. 1989. Perceived usefulness, perceived ease of use, and user acceptance of information technology. MIS Quarterly 13 (3): 319-340.

DeLone, W. H. \& McLean, E. R. 1992. Information system success: The quest for the dependent variable. Information Systems Research 3 (1): 60-95.

DeLone, W.H. \& McLean, E.R. 2003. The DeLone and McLean model of information system success: A ten-year update. Journal of Management Information Systems 19 (4): 9-30.

DeLone, W.H. \& McLean, E.R. 2016. Information systems success measurement. Foundations and Trends in Information Systems 2 (1): 1-116.

Hair, J.F., Black, W.C., Babin, B.J. \& Anderson, R.E. 2014. Multivariate Data Analysis. London: Pearson Education Limited.

Hayduk, L.A. \& Littvay, L. 2012. Should researchers use single indicators, best indicators, or multiple indicators in structural equation models? BMC Medical Research Methodology 12: 159-176.

Hussein, Z. 2018. Subjective norm and perceived enjoyment among students in influencing the intention to use e-learning. International Journal of
Civil Engineering and Technology 9 (13): 852858.

Kapo, A., Mujkic, A., Turulja, L., \& Kovacevic, J. 2020. Continuous e-learning at the workplace: The passport for the future of knowledge. Information Technology \& People. Vol. ahead-of-print No. ahead-of-print. https://doi.org/10.1108/ITP04-2020-0223

Lalic, B., Majstorovic, V., Marjanovic, U., Delic, M., $\&$ Tasic, N. 2017. The effect of industry 4.0 concepts and e-learning on manufacturing firm performance: Evidence from transitional economy. International Federation for Information Processing 513: 298-305.

Lee, B., Yoon, J., \& Lee, I. 2009. Learners' acceptance of e-learning in South Korea: Theories and results. Computers \& Education 53: 13201329.

Lee, J.W., Jones, P.S., Mineyama, Y., \& Zhang, X.E. 2002. Cultural differences in responses to a likert scale. Research in Nursing \& Health 25: 295-306.

Li, D. \& Tsai, C. 2020. Antecedents of employees' goal orientation and the effects of goal orientation on e-learning outcomes: The roles of intraorganizational environment. Sustainability 12: 112 .

Marjanovic, U., Delic, M., \& Lalic, B. 2016. Developing a model to assess the success of e-learning systems: evidence from a manufacturing company in transitional economy. Information Systems and e-Business Management 14: 253-272.

Martins, L.B., Zerbini, T., \& Medina, F.J. 2019. Impact of online training on behavioral transfer and job performance in large organization. Journal of Work and Organizational Psychology 35(1): 2737.

Mohammadi, H. 2015. Investigating users' perspectives on e-learning: An integration of TAM and IS success model. Computers in Human Behavior 45: 359-374.

Ramayah, T., Ahmad, N. H., \& Hong, T. S. 2012. An assessment of e-training effectiveness in multinational companies in Malaysia. Educational Technology \& Society 15(2): 125-137.

Rogers, E.M. 1995. Diffusion of Innovations (4th ed.). New York: Free Press.

Sawang, S., Newton, C., \& Jamieson, K. 2013. Increasing learners' satisfaction/ intention to adopt more e-learning. Education and Training 55 (1): 83-105.

Schwab, K. 2019. The Global Competitiveness Report 2019. Switzerland: World Economic Forum.

Sekaran\& Bougie. 2013. Research Method for Business: A Skill-Building Approach. New Jersey:Wiley.

Serrat, O. 2017. Knowledge Solutions: Tools, Methods, and Approaches to Drive Organizational Performance. Singapore: Springer Open.

Si, S. X. \& Cullen, J.B. 1998. Response categories and potential cultural bias: Effects of an explicit 
middle point in cross-cultural surveys. The International Journal of Organizational Analysis 6 (3): 218-230.

Stoffregen, J., Pawlowski, J.M. \& Pirkkalainen, H. 2015. A barrier framework for open e-learning in public administrations. Computers in Human Behavior 51:674-684.

Sudibjo, N., Idawati, L., \& Harsanti, H.G.R. 2019. Characteristics of learning in the era of industry 4.0 and society 5.0. Advances in Social Science, Education and Humanities Research 372: 276278.

Tam, C. \& Oliveira, T. 2016. Understanding the impact of m-banking on individual performance: DeLone \& McLean and TTF perspective. Computers in Human Behavior 61: 233-244.

Tanduklangi, A. 2017. Determinants of user intention in using e-learning technology in Indonesian context: An empirical study. Mediterranean Journal of Social Sciences 8 (3): 69-77.

Urbach, N., Smolnik, S., \& Riempp, G. 2010. An empirical investigation of employee portal success. Journal of Strategic Information Systems 19: 184-206.

Venkatesh, V., Morris, M.G., Davis, G.B., \& Davis, F.D. 2003. User acceptance of information technology: toward a unified view. MIS Quarterly 27 (3): 425-478.

Zareie, B. \& Navimipour, N. J. 2016. The effect of electronic learning systems on the employee's commitment. The International Journal of Management Education 14: 167-175. 